\title{
Labor market: problematic aspects of informal employment in Ukraine
}

\author{
Alla Bielova ${ }^{1 *}$, Nataliia Zhuravska ${ }^{2}$, Gheorghij Olijnyk ${ }^{3}$, Svetlana Koval $^{4}$, and Alona \\ Kochedykova $^{5}$ \\ ${ }^{1}$ Kyiv Institute of Innovation Education, National University of Construction and Architecture, \\ Department of Economics and Management of the GSP, Vozduhoflotsky Avenue 31, Kyiv, 03680, \\ Ukraine \\ ${ }^{2}$ National University of Construction and Architecture, Vozduhoflotsky Avenue 31, Kyiv, 03680, Ukraine \\ ${ }^{3}$ Open International University of Human Development "Ukraine", Ukraine \\ ${ }^{4}$ State Higher Educational Establishment "Pereyaslav-Khmelnyckyi State Pedagogic University named \\ Grygoriy Skovoroda", Sukhomlinsky str. 30, Pereyaslav-Khmelnitskiy, Kiev region, 08401, Ukraine \\ ${ }^{5}$ Boryspil Institute of Municipal Management at the Interregional Academy of Personnel Management, \\ Kiev Region, Ukraine
}

\begin{abstract}
The subject of the article is the study of specific problems of informal employment of people in the labor market of Ukraine by analyzing the statistical estimation of dynamics and structure of some indicators in 2015 and 2017. The study used general scientific and special statistical methods: analysis of dynamics and synthesis, analogy and comparison, expert assessments, etc. On the basis of the study of the numerical characteristics of the main indicators of the labor market, an analysis of certain aspects of the problems of the informal sector in the field of employment and unemployment in Ukraine was conducted, as well as the main prospects for their possible future solution in the modern economic conditions. It is determined that coordination of efforts of the authorities at all levels in the implementation of the employment policy and reduction of its shadowing scale is impossible without a scientifically based comprehensive national program for promoting employment aimed at ensuring a balanced supply and demand for labor in the labor market.
\end{abstract}

\section{Introduction.}

Problem statement. At present, the development of market relations in Ukraine comes along with significant changes in the employment situation, leading to new features of the functioning of the labor market. One of the biggest obstacles to creation of a new model of socio-economic development of the country currently is the high level of economic shadowing, which makes it impossible to accelerate economic reforms, increase social standards of living of the population and integration into the European community. One of the most important issues in this area is labor market transparency. The urgency of the problem of legalizing employment and wages today is due to its scale and extremely negative and devastating consequences.

\footnotetext{
* Corresponding author: $\underline{\text { nzhur@, ua.fm }}$
} 
Analysis of recent research and publications. The issue of the functioning of the labor market and the principles for its regulation have been highlighted in numerous papers by scholars, researchers, economists, sociologists, and specialists in public administration: Z.P. Baranik, D.P. Goddess, O.V. Bokova, VS Vasilchenko, M.I.The lower one, T.M. Kirian, G.I. Kupalova, E.M. Libanova, V.V. Onikienka, L.G. Rozhdestvenskaya, V.A. Savchenko, A.A.Shenchuk, G.G. Trofimova, O. M. Umansky, V.M. Chamoty, L.S. Shevchenko, L.M. Yakushenko, L.D. Yatsenko and others [2, 3].

However, at present, Ukraine lacks fundamental scientific works which would have had a comprehensive approach to studying the problems of shadow (unreported) employment in Ukraine, i.e., the use of hired labor without an employment contract and shadow wages that have been rapidly spreading in recent years, covering a large number of jobs at enterprises and organizations of the formal and informal sector of the economy.

The purpose of the article is to review and statistical analysis of processes of informal employment of the population of Ukraine in terms of its comparison with actual official employment in the labor market and further developments in this direction.

\section{The main part.}

It should be noted that under the conditions of market economy in Ukraine, informal employment is spreading rapidly, covering all informal workplaces both in the informal and formal sectors of the economy. Usually informal employment is inherent in the population of certain socio-economic groups.

Thus, in 2015 the number of informally employed population of Ukraine amounted to 4.3 million people, or $26.2 \%$ of the total employed population. Informal labor relations predominated in the self-employment sector, where the share of the population working in informal work places was $73.2 \%$, and among those employed by such persons was about $17.3 \%$ [1].

Among informally employed persons, more than one third $(38.6 \%)$ worked in agriculture, forestry and fisheries. Other common types of economic activity of the population of this category are wholesale and retail trade (22.1\%) and construction (16.1\%) [1].

In 2017, the number of informally employed population in the country decreased by 642 thousand people compared to 2015 and amounted to 3.7 million people, or $22.7 \%$ of the total number of employed population.

Thus, informal labor relations predominated in the self-employed sector, where the share of population with informal jobs was $74.3 \%$, while the number of employed persons was almost $13.1 \%$ (Table 1) [1].

Currently, people with a low level of education and those who are engaged in physical or unskilled labor are informally employed. In particular, the proportion of informally employed among the workers of the simplest professions in 2017 was significantly higher than among the officially employed (51.5\% vs. 9.6\%). Agriculture, forestry and fisheries are the main activities of the informally employed people (42.7\%). Other common types of economic activity of the population of this category are wholesale and retail trade (19.5\%) and construction (15.3\%) [1].

During 2015-2017, changes in the status of employment among the formal and informal population took place in the structure of the employed population, the increase in the share of employees was $(84.3 \%$ versus $84.1 \%)$.

Table 1. Employment of Ukrainian population by employment status and place of residence in 2015, 2017

\begin{tabular}{|l|l|l|l|c|}
\hline \multirow{2}{*}{} & \multicolumn{2}{|c|}{ Employed population } & \multicolumn{2}{c|}{ Therefrom informally occupied the population } \\
\cline { 2 - 5 } & total, & including worked & total, & including worked \\
\hline
\end{tabular}




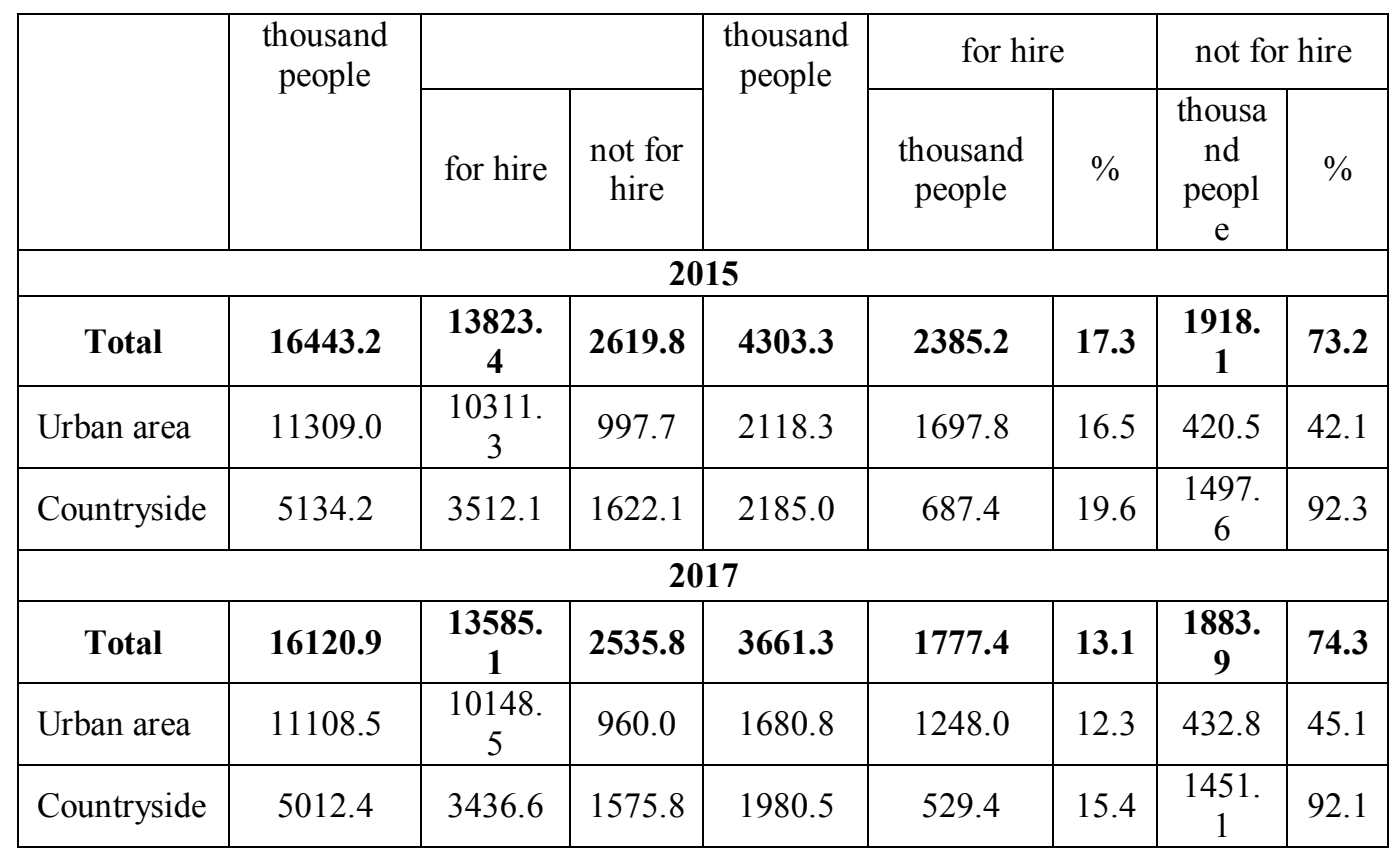

At the same time, reverse processes occurred among informally employed population (Figure 1).

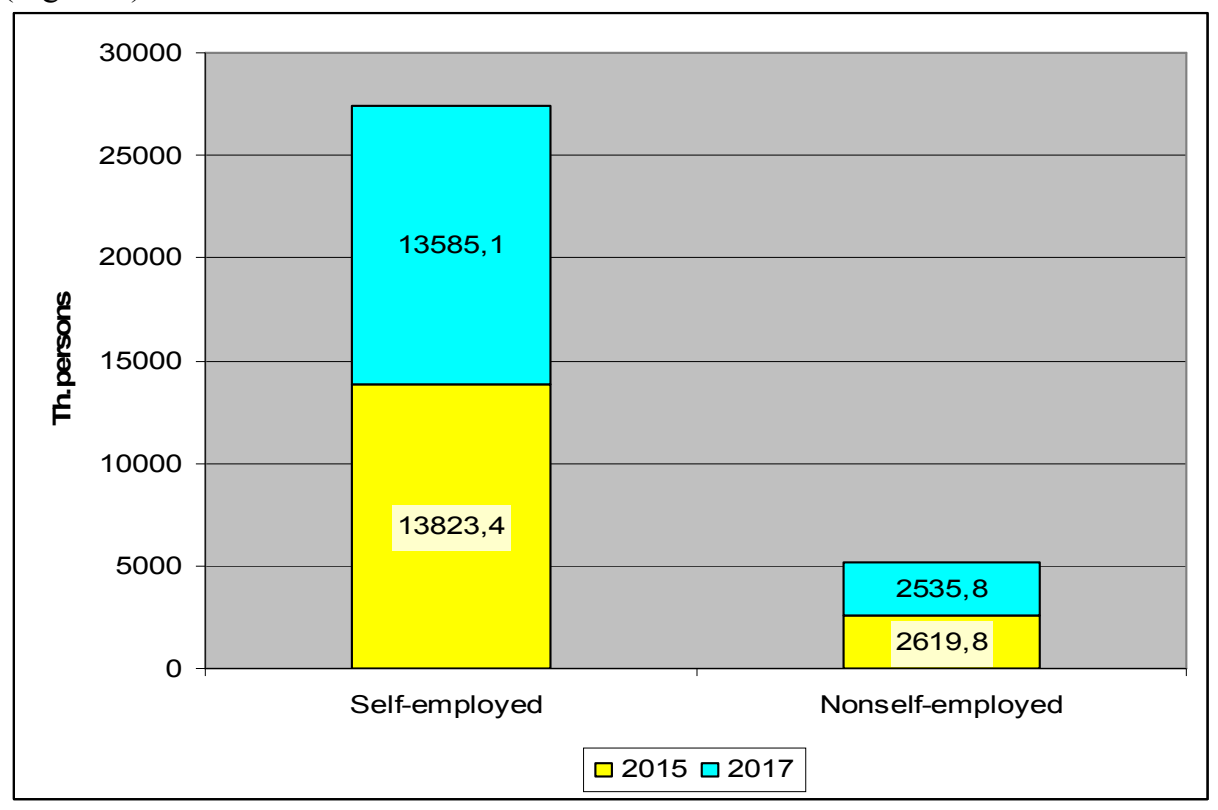

Fig. 1. Formal employment of Ukraine's population by employment status (whether employed or not) in 2015,2017

In 2017, among the informally employed population, two thirds (66.6\%) comprised persons who had vocational and full secondary education, and those with higher education (including full, basic and incomplete higher education) dominated the officially employed population $(61.5 \%)$. 
More than half of informally employed people (50.8\%) were rural residents. Men were also more likely to work informally $(58.8 \%)$, compared with women. The analysis of informal employment by age groups shows that its highest level is characteristic for persons aged 15-24 $(36.1 \%)$ and at the age of $60-70$ years $(37.2 \%)$.

Table 2. Informal employment of Ukraine by age group, gender and location in 2015, 2017

\begin{tabular}{|c|c|c|c|c|c|c|c|c|c|c|}
\hline & \multicolumn{2}{|c|}{$\begin{array}{c}\text { The number of } \\
\text { informally employed } \\
\text { population }\end{array}$} & \multicolumn{7}{|c|}{$\begin{array}{l}\text { Including by age group (years), in } \% \text { of the } \\
\text { total number of the employed population of } \\
\text { the corresponding age group }\end{array}$} & \multirow{3}{*}{$\begin{array}{l}\text { Able- } \\
\text { bodied } \\
\text { age, } \\
\text { thousand } \\
\text { persons }\end{array}$} \\
\hline & \multirow{2}{*}{$\begin{array}{c}\text { thousan } \\
\text { d } \\
\text { people }\end{array}$} & \multirow{2}{*}{$\begin{array}{l}\text { in } \% \text { of the } \\
\text { total number } \\
\text { employed }\end{array}$} & & & & & & & & \\
\hline & & & $15-24$ & $25-29$ & $30-34$ & $35-39$ & $40-45$ & $50-59$ & $60-70$ & \\
\hline & \multicolumn{10}{|c|}{2015} \\
\hline $\begin{array}{l}\text { The whole } \\
\text { population }\end{array}$ & 4303.3 & 26.2 & 36.1 & 26.8 & 25.0 & 25.6 & 24.0 & 24.0 & 37.2 & 4046.3 \\
\hline women & 1772.2 & 22.5 & 30.5 & 22.0 & 20.5 & 21.6 & 20.0 & 22.1 & 39.3 & 1626.5 \\
\hline men & 2531.1 & 29.5 & 40.4 & 30.5 & 28.6 & 29.2 & 28.1 & 25.9 & 35.0 & 2419.8 \\
\hline urban area & 2118.3 & 18.7 & 26.6 & 20.3 & 19.9 & 19.8 & 17.5 & 15.8 & 14.9 & 2052.5 \\
\hline \multirow[t]{2}{*}{ countryside } & 2185.0 & 42.6 & 49.4 & 42.0 & 40.6 & 39.7 & 37.6 & 41.5 & 74.1 & 1993.8 \\
\hline & \multicolumn{10}{|c|}{2017} \\
\hline $\begin{array}{l}\text { The whole } \\
\text { population }\end{array}$ & 3661.3 & 22.7 & \begin{tabular}{|l}
34.7 \\
\end{tabular} & 23.8 & 20.6 & 20.2 & 20.9 & 21.4 & 33.1 & 3436.3 \\
\hline women & 1506.2 & 19.4 & 28.0 & 19.9 & 15.2 & 17.7 & 17.3 & 19.9 & 33.8 & 1387.7 \\
\hline men & 2155.1 & 25.8 & 40.1 & 26.5 & 25.0 & 22.6 & 24.6 & 23.0 & 32.5 & 2048.6 \\
\hline urban area & 1680.8 & 15.1 & 23.6 & 18.0 & 15.3 & 14.6 & 14.1 & 13.1 & 11.7 & 1631.3 \\
\hline countryside & 1980.5 & 39.5 & 50.0 & 35.7 & 35.9 & 35.1 & 35.7 & 39.5 & 68.5 & 1805.0 \\
\hline
\end{tabular}

In most cases, the youth nature of informal employment is manifested in the need for additional earnings during education. In 2015, more than two-thirds $(67.5 \%)$ of the informally employed population consisted of those who had vocational and general secondary education, and those with a higher education, including full, basic and incomplete higher education, were prevalent among the officially employed population $-61.8 \%$.

In 2017, the most widespread informal employment was among young people aged 15-24 years, as well as persons aged 60-70. These categories of the population are more vulnerable and socially unprotected in modern economic conditions. 
The spread of informal employment among the retirement age is primarily due to the low level of pensions, which prompts them to seek informal sources of additional livelihoods. Among women, the share of non-employed people exceeded the corresponding indicator among men $(76.1 \%$ vs. $73.0 \%)$, and in rural areas it was twice as high as in urban settlements $(92.1 \%$ and $45.1 \%$ ) (Table 2) [1].

In the total number of the employed population of Ukraine in 2017 in the twelve regions of the country, the proportion of informally employed persons did not exceed the average in Ukraine (22.7\%). The largest value of this indicator was observed in Chernivtsi region (50.9\%), and the smallest in the Kiev region (9.4\%), (Figure 2) [1].

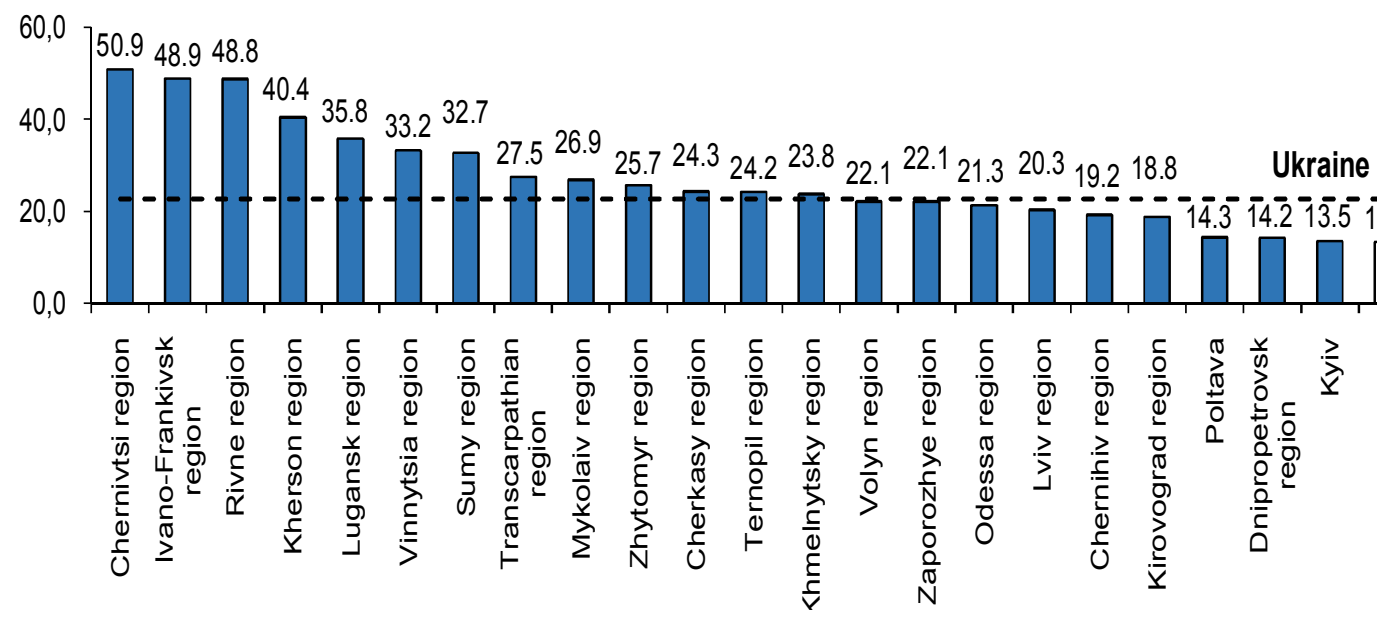

Fig. 2. Informal employment of the population of Ukraine by regions in 2017 [1] (in \% to the number of employed population in the region concerned)

\section{Conclusions}

Consequently, the current state of the labor market of Ukraine is characterized by unfavorable trends in the level of employment and ineffective use of labor force. At this time, shadow occupation has become extremely widespread, with negative consequences for both the state and employees.

Coordination of efforts of the authorities at all levels in implementing the employment policy and reducing the scope of its shadowing is impossible without a scientifically based comprehensive national program to promote employment, aimed at ensuring a balanced supply and demand for labor in the labor market. Therefore, one of the main tasks of the Ukrainian state policy should be the concentration of efforts of all branches of power on the complex implementation of drastic economic, administrative and organizational measures to legalize the employment of the population in the Ukrainian labor market.

\section{References}

1. Official site of the State Statistics Service of Ukraine. URL: http://www.ukrstat.gov.ua/.

2. A. I. Belova, A. E. Kočedikova. Economics and Society. 7, 201-205 (2016) URL: http://economyansociety.in.ua. 
3. B. M. Danylyshyn, V.V. Mykytenko - In 2 t. - Vol. 2. - K.: RVPS of Ukraine, National Academy of Sciences of Ukraine, Vyd. CJSC "Nichlava", 210 (2008).

4. Senchuk A. The Strategy of Sustainable Development "Ukraine-2020" - the Way to a Better Future. External affairs. 8, (2014). URL: http://uaforeignaffairs.com/ua/zs/anglomovna-versija/view/article/ strategy-stalogorozvitku-ukrajina-2020-shljakh-do-kr/.

5. Yatsenko L. D., Yakushenko L. M. Analytical report of the Department of Social Policy, Kyiv, 2016. URL: http://ndei.me.gov.ua/index.php?option=com_content\&view=article\&id $=203 \&$ Itemid $=89 /$.

6. Nesterova T.Yu., Sviridova S.V. System Concept of Management of Industrial Enterprise in the Development of Information Technologies. Innovative Bulletin Region, 2011. - No. 2.6. Bruce Stokes. Deep Cuts: What the Age of Austerity Means for Global Public Goods. Brussels Forum, March, 2011. - Access: http: blogs.cgdev.org.

7. B. M. Andrushkiw, N.B. Kyrych, O.B. Pohaydak. Journal of economics of Ukraine: Scientific journal. 1 (21)., 3-5 (2012).

8. Modernization of state support of business entities in Ukraine: analytical note. - C.: Izd NISS under the President of Ukraine,128 (2013).

9. C. Fellenshtein. Exploring E-commerce, Global E-biness and E-societies. Upper Saddle River: Prentice-Hall, 2000. - 269 p.

10. Global Internet and E-Commerce Trends 2017. Stats.com GmbH \& Co. KG, 251, (2018).

11. Smolyanyuk P. Economic Analysis. 5. 332, 336. 2010. Ternopil. TNEU 